\title{
Human Value Manifest in Instagram: A Visual Content Analysis of DMO Photography
}

\author{
Taufiqqurrachman* \\ School of Journalism and Information Communication, Huazhong University of Science \& Technology, 1037 \\ Luoyu Rd. Wuhan 430074, China. \\ * E-mail of the corresponding author: I201622042@Hust.edu.cn
}

\begin{abstract}
The relationship of social media and tourism marketing through image projection by which visual content is produced was well documented. However, minimal research was reported on the human values promoted through the usage of social media in the context of marketing tourism by various elements of Destination Management Organization (DMO), such as government, tourism industry, and official marketing agency. Since visual content was widely used to attract visitors, this paper aims to highlight and discuss the prominent human values within photographs posted on Instagram of the three categories of DMO. Visual content analysis was applied to measure those values promoted through the collected photograph. Findings of this study shown values classified into self-transcendence and conservation categories are more prominent than those of selfenhancement and openness within Instagram of all marketer categories. Both theoretical and managerial implications of this study to tourism study were discussed.
\end{abstract}

Keywords: Instagram, Human Value, Photography, Tourism Marketing

DOI: $10.7176 / \mathrm{NMMC} / 80-06$

Publication date:May $31^{\text {st }} 2019$

\section{Introduction}

Value is significant in marketing since it influences on consumer behavior (Sheth, Newman and Gross, 1991), including tourist behavior (Mok and Defranco, 2008). In marketing literature, several perspectives were used by scholars to study the relationship of value and marketing, such as cost-benefit (Zeithaml, 1988) and (Lassar, Mittal and Sharma, 1995), multidimensional construct (Sheth, Newman and Gross, 1991) and (Sweeney and Soutar, 2001). Meanwhile, some scholars relate human values developed by (Schwartz, 1994) to product purchasing (Allen, 2002), (Allen, 2008), (Allen and Ng, 2003), (Torelli, Özsomer, Carvalho, Keh, \& Maehle. 2012), mainly destination selection (Saji and Vij and Kabiraj 2015).

At the same time, other literature demonstrate social media is believed as trusty information source for tourist's trip planning (Yoo and Gretzel, 2010), (Akehurst, 2009) and play an important role in traveler's destination selection (Xiang and Gretzel, 2010) (Parra-lópez, Bulchand-Gidumal, Gutiérrez-Taño, and Díaz-Armas 2011), (Sparks and Browning, 2011).

In addition, some other previous studies also presented the significant role of online media in destination marketing, particularly through tourist's image formation (Dwivedi, 2009), ( Kim, Lee, Shin \& Yang 2017) and (Xiang Li, Bing Pan, Lixuan Zhang 2009), (Alvarez and Korzay 2008) (Hahm and Wang, 2011), (Young, Young and Young, 2008), (Wang, Chan and Pan, 2014), (Muhoho-minni and Lubbe, 2017), (Dolores M. Frias, Miguel A. Rodriguez, J. Alberto Castaneda, 2011).

In line with those revealed findings, thousands of photographs are circulated within internet network by social media accounts of Destination Management Organizations (DMO), since they are believed as factor of tourism marketing (Mackay and Couldwell, 2004), (Stepchenkova and Zhan, 2013), (Lian and Yu 2017), (Bernkopf and Nixon, 2018). While some other studies identified tourism place were culturally and socially constructed by the circulation of photographs through various form of media (Mercille, 2005), (Bandyopadhyay, 2011), (Grossmanthompson, 2016), (Jenkins 2003), (Schellhorn and Perkins 2010), (Nelson, 2005).

However, there is still a lack of study examining the relationship between media and tourism marketing through which human values are associated with the tourism destination. To fulfill the existing gap still left by tourism literature, this article examines the relationship of human values and destination marketing through photograph posted within social media. Since various DMO, both public and private take a part in the process of destination marketing (branding) (Kavaratzis and Ashworth, 2005), this study take social media account owned by three elements of stakeholders (government, tourism industry and marketing agency) to understand the differences 
human values associated to the Bali island by these differences of DMO elements.

On the one hand, Instagram is widely used by marketer through producing and sharing visual contents (Teo, Leng and Phua, 2018), (Bernkopf and Nixon, 2018). As this social media platform provide some features to facilitate visual content sharing and posting, such as video, photo (Minazzi, 2015). On the other hand, as mentioned earlier this article aims to examine human value associated with Bali Island as a tourism destination through visual content production. By considering these two different sides, Instagram is taken in this study as a social media platform used by the three elements of DMO in the context of marketing Bali island.

\section{Literature Review}

\subsection{Social Media Usage in Destination Marketing}

Social media also known as web 2.0 and user-generated-content media is the next generation created by the innovation of information and communication technology. Minazzi (2015: 5) classified this media into some categories, such as: collaborative projects (i.e., Wikipedia), virtual communities on which user can share information in various format (i.e., twitter, personal blog, virtual tourist, trip advisor), content communities in which video, photo, and other content formats are shared through these websites (i.e., BookCrossing, Youtube, Flickr, Pinterest, Instagram, etc.), social network sites (i.e., Facebook, Linkedin etc.), virtual games/social worlds platforms.

In tourism practices, social media are used by both DMO (Destination Management Organization) and tourists. For DMO, social media, mainly blog was considered as marketing toll functioned for promotion, product distribution, communication, management and research (Schmallegger and Carson, 2008). Also, for tourist social media usage aimed to share comments and opinions about experiences and tourism products (Inversini, Cantoni and Buhalis, 2009), travel knowledge (Huang, Basu and Hsu, 2010), and travel photos (Lo, McKercher, Lo, Chung and Law 2011).

In particular, the study of Huang et al. (2010) identified obtaining travel information, information dissemination, and personal documentation were among factors that motivated these information sharing activities. Meanwhile, some other literature examined the effects of social media as source information toward tourist behavior within the context of tourism marketing. Yoo and Gretzel (2010, 2011) and Ayeh, Au, and Law (2013) found tourist's usage of social media influenced their trip planning. Notably, the study of Yoo and Gretzel (2010) indicated travel-related CGM (Content-Generated Media) had become a valuable information source for travelers as more than half of online travelers used CGM for their recent overnight pleasure trip planning, and the majority trusted these contents.

Following those findings, the work of (Akehurst, 2009) indicated tourists perceived blogs as more credible and trustworthy than traditional marketing communications. In contrast, Cox, Burgess, and Sellitto (2009) revealed amid its rising popularity, social media is still not yet seen as credible or trustworthy, while tourist tends to trust information derived from the official source of tourism information. Consequently, social media were positioned as an additional source of information.

Xiang and Gretzel (2010), Parra-lópez et al. (2011) and Sparks and Browning (2011) by studying tourist's social media usage also suggested the role of social media in destination selection. But their findings varied to each other because of the different issue addressed by those studies. Xiang and Gretzel (2010) found online traveler interact with a search engine to access the online tourism domain, including social media websites/ web pages. By this, these authors argued the impact of social media on tourism marketing is indirect, while the search engine mediated their interaction (users and social media).

In contrast to the work of Xiang and Gretzel (2010), Sparks and Browning (2011) emphasized the importance of consumer evaluations. By this study, they found an online review influenced on willingness to purchase tourism products, particularly to book a room at a targeted hotel as well as on the perception of trust in the hotel.

Whereas, some other studies investigated the role of online media, including social media in destination promotion through tourist's image formation. By applying net-ethnographic, Dwivedi (2009) questioned how online communities use the internet in the process of destination image formation. He found that these users not only perceive destination image portrayed by online resources but actively they construct and share their own pictures via the internet.

Li conducted a similar study, Pan, Zhang \& Smith (2009) focusing on the relationship between online information searching with the formation of China tourism destination image. The study demonstrates that online 
travel planning exercise gives effect to the change of the user's overall image and affective image. Kim et al. (2017) measured the influence of content and non-content cues of tourism information quality in social media (Sina Weibo) on the formation of three components of the image: cognitive, affective and conative. The findings of this study indicated that most Chinese tourists (81\%) consider social media as an important source for obtaining tourism information. Other findings showed most content cues of tourism information affected either cognitive or affective image. Meanwhile, the web page design is the only variable as non-content cues of information which affect cognitive image formation.

\subsection{The Significance of Human Values in Marketing}

Generally, value is one of the central subjects of marketing studies, as it is considered to influence consumer behavior (Sheth et al., 1991). Several perspectives were developed by marketing scholars to define the concept of values, such as cost-benefit (Zeithaml. 1988) and (Lassar et al.,1995), multidimensional construct (Sheth et al., 1991) and (Sweeney and Soutar, 2001).

The concept of human value is specifically highlighted in this section, since it is the main topic of this study. Initially, human values were conceptualized by Rokeach (1973) and Schwartz (1992, 2012). Rokeach (1973:5) defined human value as "an enduring belief that a specific mode of conduct or end state of existence is personally or socially preferable to an opposite or converse mode of conduct or end state of existence". This scholar categorizes two kinds of values: instrumental and terminal values. Instrumental values reflect modes of conduct and behavioral characteristics an away to reach terminal values. Whereas, terminal values reflect end states of existence or a desirable end state in life that an individual would like to achieve.

Then, Schwartz (1994) developed further Rokeach's human value theory by organizing them in a four-level hierarchy. The first is four levels of higher order value types, including Openness to change, conservative, selfenhancement and self-transcendence. Those value types contain bipolar dimension elements that conflict with one another: openness to change versus conservative and Self-enhancement versus Self-transcendence.

The second is ten motivational value types, including power, achievement, hedonism, stimulation, self-direction, universalism, benevolence, tradition, conformity, and security. The third is fundamental human values derived from each of 10 motivational value types. Each of them originated from different sources, such as interaction, group, and organism. The fourth level hierarchy, value definition, and their sources are illustrated in table (1).

In fact, Schwartz's human values are applied by some scholars for several contexts of study, for instance: teaching (Cohen, 2010), organization (Cohen, 2009), social media practice (Koepfler and Fleischmann, 2011), personality development (Heaven, 1993). Particularly in marketing, empirical evidence showing consumers' choice of products was influenced both directly and indirectly by his personal values (Allen, 2008) (Allen and $\mathrm{Ng}, 2003)$.

Other study demonstrated the relationship of human value and product are mediated by a cognitive process through which the customers compare the human values symbolized by a product and the human values that they endorse (Allen, 2002). The significance of human values within product purchasing is also shown by Torelli et al. (2012) as they are represented in the brand. However, this scholar views its significance is mediated by cultural differences (individualism and collectivism). Since, he argued consumers compare their cultural values and human values represented in the brand before deciding to purchase. Saji et al. (2015) further developed and applied this relationship into the context of tourist's destination selection by associating cultural differences with human value and then associating these values with the category of the destination location. This study concluded the tourist adjust his personal values with the values attached to the destination. 
Table. 1. Conceptualization of human value (Schwartz 1994)

\begin{tabular}{|c|c|c|c|c|}
\hline $\begin{array}{l}\text { Higher Order } \\
\text { Type of Values }\end{array}$ & $\begin{array}{c}\text { Value } \\
\text { Dimension }\end{array}$ & Definition & Exemplary values & Sources \\
\hline \multirow[t]{2}{*}{$\begin{array}{l}\text { Self-enhancement } \\
\text { (S-E) }\end{array}$} & Power & $\begin{array}{l}\text { Social status, prestige, control } \\
\text { or dominance over people, } \\
\text { and resources }\end{array}$ & Social power, authority, wealth & $\begin{array}{l}\text { Interaction } \\
\text { group }\end{array}$ \\
\hline & Achievement & $\begin{array}{l}\text { Personal success through } \\
\text { demonstrating competence } \\
\text { according to social standards }\end{array}$ & $\begin{array}{l}\text { Success, capability, ambitions, } \\
\text { influence on people and events }\end{array}$ & $\begin{array}{l}\text { Interaction } \\
\text { group }\end{array}$ \\
\hline \multirow[t]{2}{*}{ Openness (OP) } & Stimulation & $\begin{array}{l}\text { Excitement, novelty, a } \\
\text { challenge in life }\end{array}$ & $\begin{array}{l}\text { Daring and varied challenge and } \\
\text { exciting life }\end{array}$ & Organism \\
\hline & Self-direction & $\begin{array}{l}\text { Independent, thought and } \\
\text { action, choosing, creating, } \\
\text { exploring }\end{array}$ & $\begin{array}{l}\text { Creativity, curiosity, } \\
\text { Freedom }\end{array}$ & $\begin{array}{l}\text { Organism } \\
\text { interaction }\end{array}$ \\
\hline \multirow[t]{2}{*}{$\begin{array}{l}\text { Self- } \\
\text { transcendence }(\mathrm{S}- \\
\mathrm{T})\end{array}$} & Universalism & $\begin{array}{l}\text { Understanding, appreciation, } \\
\text { tolerance, and protection of } \\
\text { the welfare for all people and } \\
\text { for nature }\end{array}$ & $\begin{array}{l}\text { Broadmindedness, social justice } \\
\text { and the world of peace, equality, } \\
\text { and wisdom, } \\
\text { The beauty of nature, unity with } \\
\text { nature, environmental protection }\end{array}$ & $\begin{array}{l}\text { Group } \\
\text { Organism }\end{array}$ \\
\hline & Benevolence & $\begin{array}{l}\text { Preservation, welfare, and } \\
\text { enhancement of people one } \\
\text { whom one is in frequent } \\
\text { personal contact }\end{array}$ & $\begin{array}{r}\text { honesty, } \\
\text { loyalty, }\end{array}$ & $\begin{array}{l}\text { Organism } \\
\text { Interaction } \\
\text { Group }\end{array}$ \\
\hline \multirow[t]{3}{*}{$\begin{array}{l}\text { Conservation } \\
(\mathrm{CV})\end{array}$} & Tradition & $\begin{array}{l}\text { Respect, commitment, } \\
\text { acceptance of the customs } \\
\text { and ideas that traditional } \\
\text { culture or religion provide }\end{array}$ & $\begin{array}{l}\text { Respect for tradition, } \\
\text { humbleness, accepting one's } \\
\text { portion in life, devotion, and } \\
\text { modesty }\end{array}$ & Group \\
\hline & Conformity & $\begin{array}{l}\text { Restraint of actions, } \\
\text { inclinations, and impulses } \\
\text { likely to upset or harm others } \\
\begin{array}{l}\text { and violate } \\
\text { expectations }\end{array} \\
\end{array}$ & $\begin{array}{l}\text { Obedience, honoring parents, and } \\
\text { elders, self-discipline, politeness }\end{array}$ & $\begin{array}{l}\text { Interaction } \\
\text { group }\end{array}$ \\
\hline & Security & $\begin{array}{l}\text { Safety, harmony, and stability } \\
\text { of society and self }\end{array}$ & $\begin{array}{l}\text { National security, family security, } \\
\text { social order, cleanliness, } \\
\text { reciprocation of favors }\end{array}$ & $\begin{array}{l}\text { Organism } \\
\text { Interaction } \\
\text { Group }\end{array}$ \\
\hline None & Hedonism & $\begin{array}{l}\text { Pleasure, sensuous } \\
\text { gratification of oneself }\end{array}$ & $\begin{array}{l}\text { The gratification of desire, } \\
\text { enjoyment in life and self- } \\
\text { indulgence }\end{array}$ & Organism \\
\hline
\end{tabular}

\subsection{Photographs in Tourism}

The relationship between tourism and photograph was theorized by Urry (2002) with his notion tourist gaze. He argued tourism practices involve the construction of the tourist gaze through which photographs capturing certain objects were produced. Then, Jenkins (2003) introduced the concept of a circuit of representation to explain the how the DMO relate to tourist through which photograph is produced by DMO for the projection of image and then the photograph is perceived and evaluated by tourist after visitation.

In practice, this kind of visual contents were widely used for the purpose of marketing (Belch \& Belch, 2014), including tourism marketing, since they are believed to attract tourist as well as stimulated a behavioral intention (Decrop 2007) dan generated image of tourist attraction (Mackay and Couldwell 2004) and improved destination image (Bernkopf and Nixon 2019). It as shown by some previous studies in which distinct form of media was used for image formation through the circulation of pictures, such as the image of Australia (Jenkin 2003), Peru (Stepchenkova and Zhan 2013), Huangshan, China (Lian and Yu 2017), Turkey.

Likewise, other studies demonstrate photographs circulated by different forms of tourism media are used to construct tourism place culturally. For instance, Schellhorn and Perkins (2004) revealed photos distributed by German-language brochures attach some features to the South Pacific islands for tourism marketing, such as Intact, un-spoilt, enduring, and feminized paradise, destination promising security, comfort, and reliability. Besides, Nelson (2005) by analyzing 350 photos derived from tourism promotion media found Granada's 
destination is constructed as other. Similar findings are presented in the work of Barbara Grossman-Thompson and Benjamin Linder (2015) in which Chitwan National Park and Bardia National Park in Nepal is constructed as other through visual content derived from the national tourism brochures.

This discussion implies visual contents produced by tourism marketing media can be viewed both in marketing approach in which they are produced for destination promotion and cultural geography approach in which through visual content cultural meaning is attached to the highlighted destination. Since values are assumed significant for marketing, this study view photograph as material marketing content constructed and circulated by media to promote human values.

\section{Methods}

Place, including tourism place was marketed by several elements of DMO, both private and public (Kavaratzis \& Ashworth: 2005) by which power (Marzano and Scott, 2009), (Ryan and Zahra 2004) or cooperation (Cai, 2002) were exercised. Also, Nash (1996) explained tourists, locals and government ministries, travel agents and tourism promotion boards are some actors taking apart in the production of tourism place meaning.

At the same time, Instagram was a social media platform widely used for marketing through which visual contents are produced and distributed (Teo, et al. 2018), (Bernkopf and Nixon, 2019). Similarly, Bali tourism also is marketed by those different actors: government (Indonesia tourism ministry), local tourism industry and marketing agency. To understand the differences in human values represented by those variations of DMO, one Instagram account representing the three categories of DMO is taken. They are Indonesia.Travel, Baligolive and Bali Tourism Promotion Board (BTPB).

First, Indonesia.wonderful was an Instagram account owned and used by Indonesia tourism ministry for marketing Indonesia tourism destination, including Bali island. This Instagram was taken to represent the government category. Second, "Baligolive" was an agency of Bali's destination marketing. In fact, the agency markets Bali through several digital media platforms. As this study focused on Instagram, its Instagram account was taken to represent local agency marketing. The last, Bali Tourism Promotion Board was an official association of local tourism industry players. The association was aimed mainly to promote Bali's tourist destinations by using several social media platforms as "Baligolive" do. Then BTPB's Instagram account was selected as a participant of this study. Those three Instagram accounts were presented in table (3).

Content analysis is a method developed for measuring values within a recorded form of communication (Cheng and Fleischmann 2010). A photograph is a recorded and documented form of communication produced visually. Therefore, I adopted visual content analysis in this study to measure human value represented by visual content posted within the three determined Instagram accounts. In particular, visual content analysis is applied through some stages: image collections, category development, coding, analyzing data (Rose 2001). These four stages were used in this study for analyzing all collected visual data.

The first, data of this study was pictures posted no later than January 20, 2019, within the three Instagram accounts representing the three categories of Bali's DMO. These photos were obtained by downloading them directly from those selected Instagram accounts and then listed into table of data population. The total amount of data, both derived from all selected Instagram accounts and from each Instagram account were presented in table 3. The process of these photos collection was carried out for 4 months from October 2018 to January 2019. The second, ten human values conceptualized by Schwartz, (1992, 1994, 2012) were used as a framework for image category development.

The third, all collected photographs were coded to determine the value represented. A predetermined category guides this coding process by using "Atlast.ti” application. All types of image and the guidelines for coding were presented in table (2). The fourth, all data that has been decoded is then tabulated and analyzed using SPSS application to find out the distribution of all data based on the categories of images.

\section{Findings}

This study found 1058 photographs relevant to the association of human values with Bali island. The entire visual data was contributed by three Instagram account representing three categories of DMO with the following details. Indonesia.Travel contributed (188 photographs), Baligolive (635 Photographs) and BTB (235 photographs).

These 188 photographs of Indonesia. Travel were distributed into ten item values. As presented in the table, self- 
transcendence values obtained the highest number of data, as shown by 110 photographs (accumulation of UV and $\mathrm{BE}$ number), conservation reached 41 photographs (accumulation of TR, $\mathrm{CO}$, and SE number), followed by Hedonism with 14 photographs. Lastly, self-enhancement reached only 1 photograph. Likewise, the 635 photographs of Baligolive were distributed dominantly into self-transcendence values with 302 photographs, followed by Conservation with 166 photographs, then, Hedonism with 86 photographs and finally selfenhancement with 0 photograph.

Finally, 235 photographs of BTPB also were distributed mostly into self-transcendence as shown by 170 photographs, followed by conservation with 34 photographs, hedonism with 14 photographs and the last selfenhancement with 0 photograph. Some photographs taken from all categories of tourism marketing agency promoting those prominent values were presented in figure 1, 2 and 3.

Table. 2 Description of images categories

\begin{tabular}{|l|l|}
\hline Value Dimensions & \multicolumn{1}{c|}{ Description } \\
\hline Power (PO) & $\begin{array}{l}\text { "PO" refers to tourist's image showing his social dominance, authority and wealth within a } \\
\text { group. }\end{array}$ \\
\hline Achievement (AV) & $\begin{array}{l}\text { Tourist's image in a social group depicting success, capability, ambitions and his influence on } \\
\text { others is coded as "AV". }\end{array}$ \\
\hline Stimulation (ST) & $\begin{array}{l}\text { "ST" refers to tourist's image seeking excitement, novelty, a challenge in a portrayed } \\
\text { destination. }\end{array}$ \\
\hline Self-direction (SD) & $\begin{array}{l}\text { SD refers to an image of tourist showing creativity, curiosity, and freedom in a depicted } \\
\text { destination. }\end{array}$ \\
\hline Universalism (UV) & $\begin{array}{l}\text { "UV" refers to an image of tourist showing understanding, appreciation, tolerance and } \\
\text { participating in the protection of people and nature welfare within a group of tourists. Also, } \\
\text { Image of beautiful nature and tourist uniting with nature is coded as "UV". }\end{array}$ \\
\hline Benevolence (BE) & $\begin{array}{l}\text { "BE" refers to an image of tourist demonstrating helpfulness, honesty, forgiveness, loyalty, a } \\
\text { responsibility to other people. }\end{array}$ \\
\hline Tradition (TR) & $\begin{array}{l}\text { "TR" refers to tourist's image indicating respect for tradition, humbleness, accepting one's } \\
\text { portion in life devotion and modesty within an interacting group }\end{array}$ \\
\hline Conformity (CF) & $\begin{array}{l}\text { "CF" refers to an image of tourist showing obedience, honoring parents and elders, self- } \\
\text { discipline, politeness to a person with whom one frequently interacts, such as parents, bosses, } \\
\text { older people as a member of a family group. }\end{array}$ \\
\hline Security (SE) & $\begin{array}{l}\text { "SE" refers to security, safety, harmony, social order, cleanliness within the social life of a } \\
\text { tourist group. Besides, tourist' image showing reciprocation of favors is coded as SE. }\end{array}$ \\
\hline Hedonism (HE) & $\begin{array}{l}\text { "HE" refers to an image of tourist gratifying desires, enjoyment in destination and self- } \\
\text { indulgence. }\end{array}$ \\
\hline
\end{tabular}

Tabel 3. Data distribution

\begin{tabular}{|c|c|c|c|c|c|c|c|c|c|c|c|c|}
\hline \multirow{3}{*}{$\begin{array}{l}\mathbf{N} \\
\mathbf{0}\end{array}$} & \multirow[t]{3}{*}{ Social media categories } & \multicolumn{10}{|c|}{ Types of Human Value } & \multirow[t]{3}{*}{ Total } \\
\hline & & \multicolumn{2}{|c|}{ S-T } & \multicolumn{2}{|c|}{ OP } & \multicolumn{2}{|c|}{ S-T } & \multicolumn{3}{|c|}{$\mathbf{C V}$} & None & \\
\hline & & PO & $\mathbf{A C}$ & ST & SD & $\mathbf{U V}$ & BE & TR & $\mathbf{C O}$ & SE & HE & \\
\hline 1 & $\begin{array}{l}\text { Government } \\
\text { (Indonesia.Travel) }\end{array}$ & 1 & 0 & 24 & 0 & 107 & 3 & 18 & 0 & 21 & 14 & 188 \\
\hline 2 & $\begin{array}{l}\text { Bali tourism marketing } \\
\text { agency (BaliGoLive) }\end{array}$ & 0 & 0 & 76 & 5 & 287 & 15 & 94 & 0 & 72 & 86 & 635 \\
\hline \multicolumn{2}{|c|}{ Sum of each value item } & 1 & 0 & 104 & 8 & 508 & 74 & 141 & 0 & 108 & 114 & 1058 \\
\hline \multicolumn{2}{|c|}{ Sum of Each Value Type } & \multicolumn{2}{|c|}{1} & \multicolumn{2}{|c|}{112} & \multicolumn{2}{|c|}{582} & \multicolumn{3}{|c|}{249} & 114 & 1058 \\
\hline
\end{tabular}




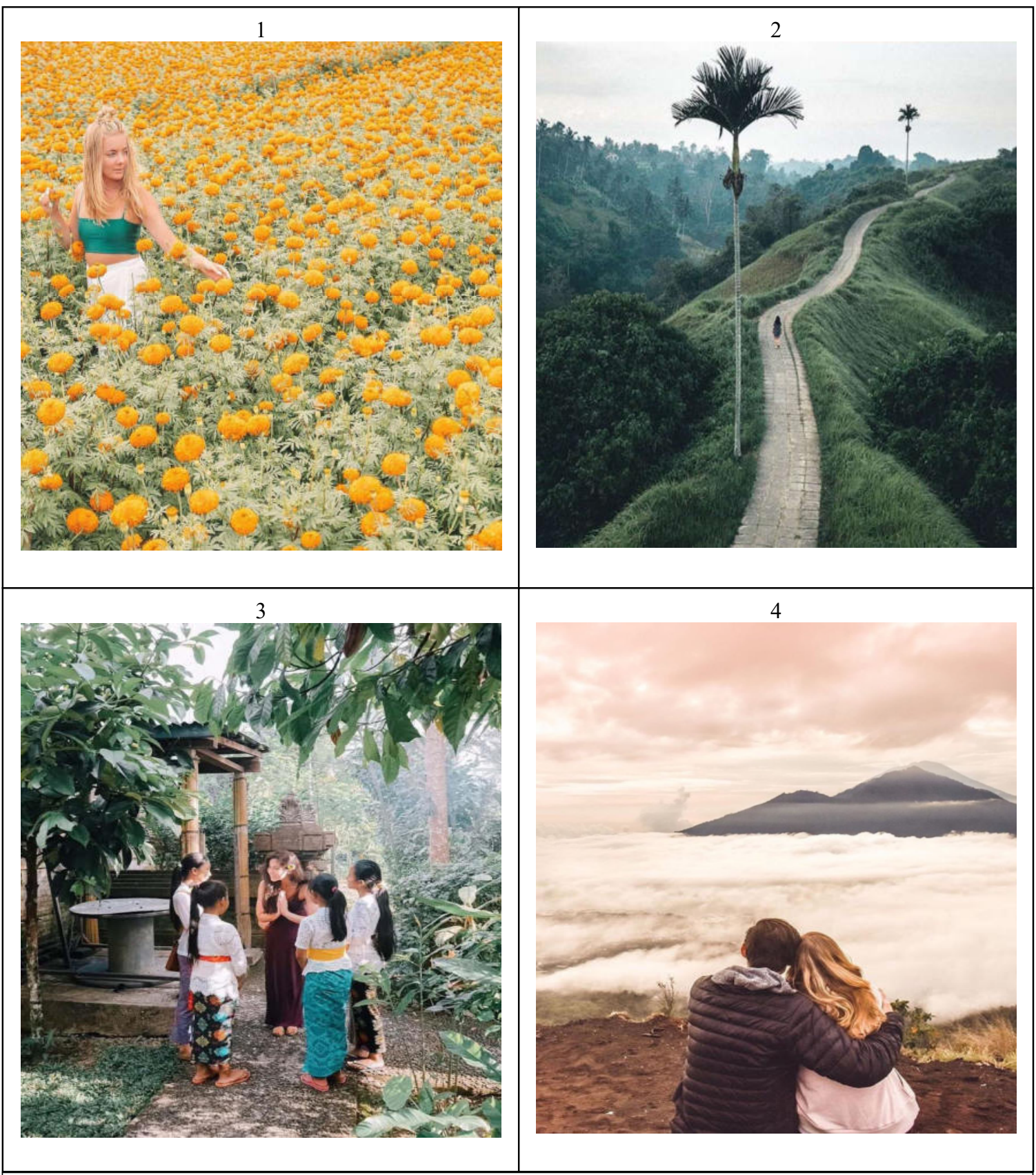

Figure 1. Indonesia.Travel's Pictures. Self-transcendence is reflected in picture 1 and 2 by which tourists are depicted to adjust herself to Bali's natural destinations. Meanwhile, the image of a tourist practicing traditional Balinese dance with a local Balinese woman is coded as a tradition (picture 3) as well as an image of a pair of tourists enjoying a natural destination is coded as security (picture 4). 


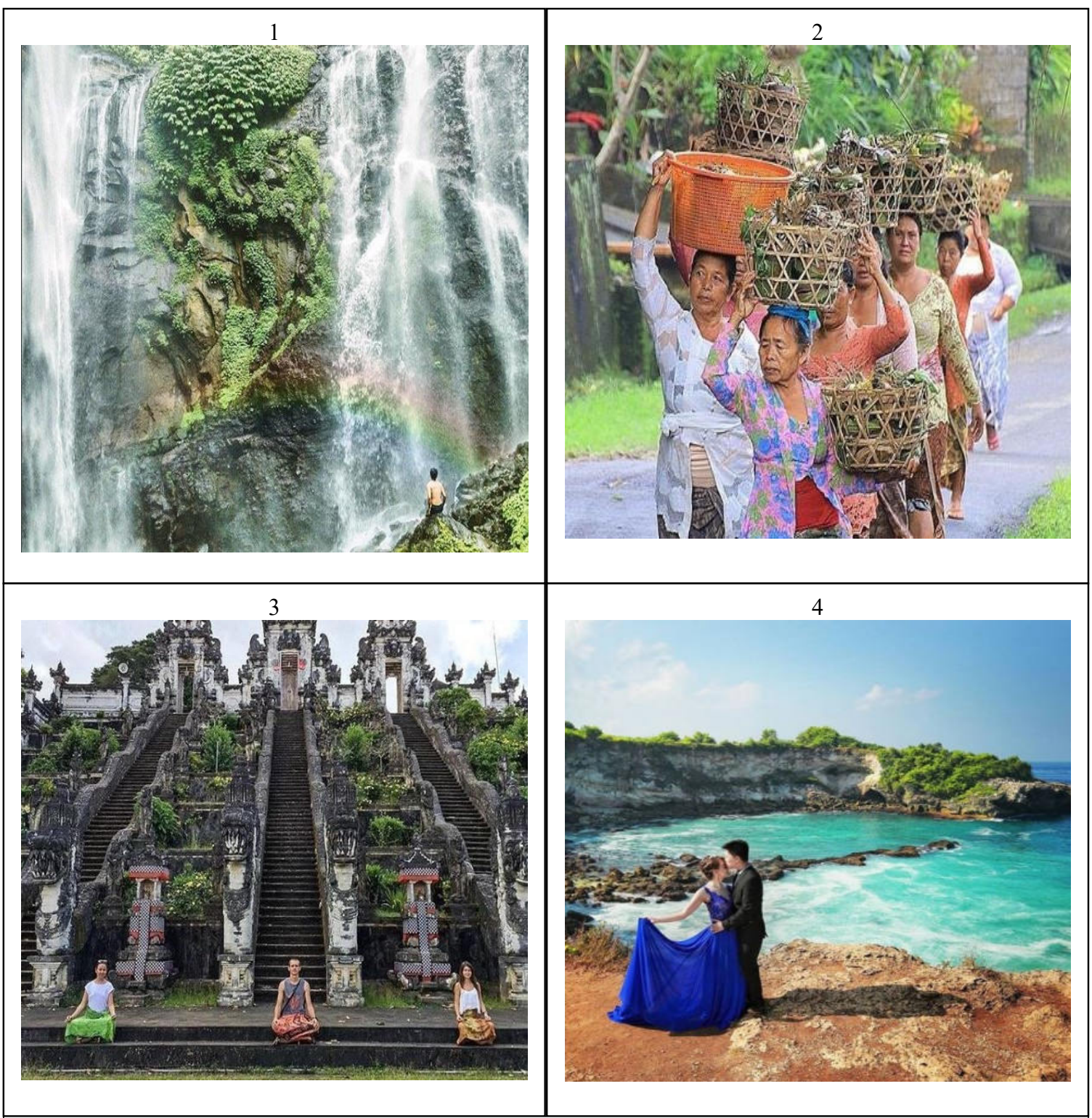

Figure 2. Baligolive's Pictures: Universalism is reflected by the pose of a tourist against the background of Balinese natural beauty (picture 1). this value is also reflected by the image of the cooperation of local workers in carrying out their daily routines (picture 2). Tradition is depicted by a tourist pose with a Balinese temple background wearing traditional Balinese fabric (picture 3). The value of the security is indicated by the intimacy of lovers posing on Bali's beach destinations (picture 4) 


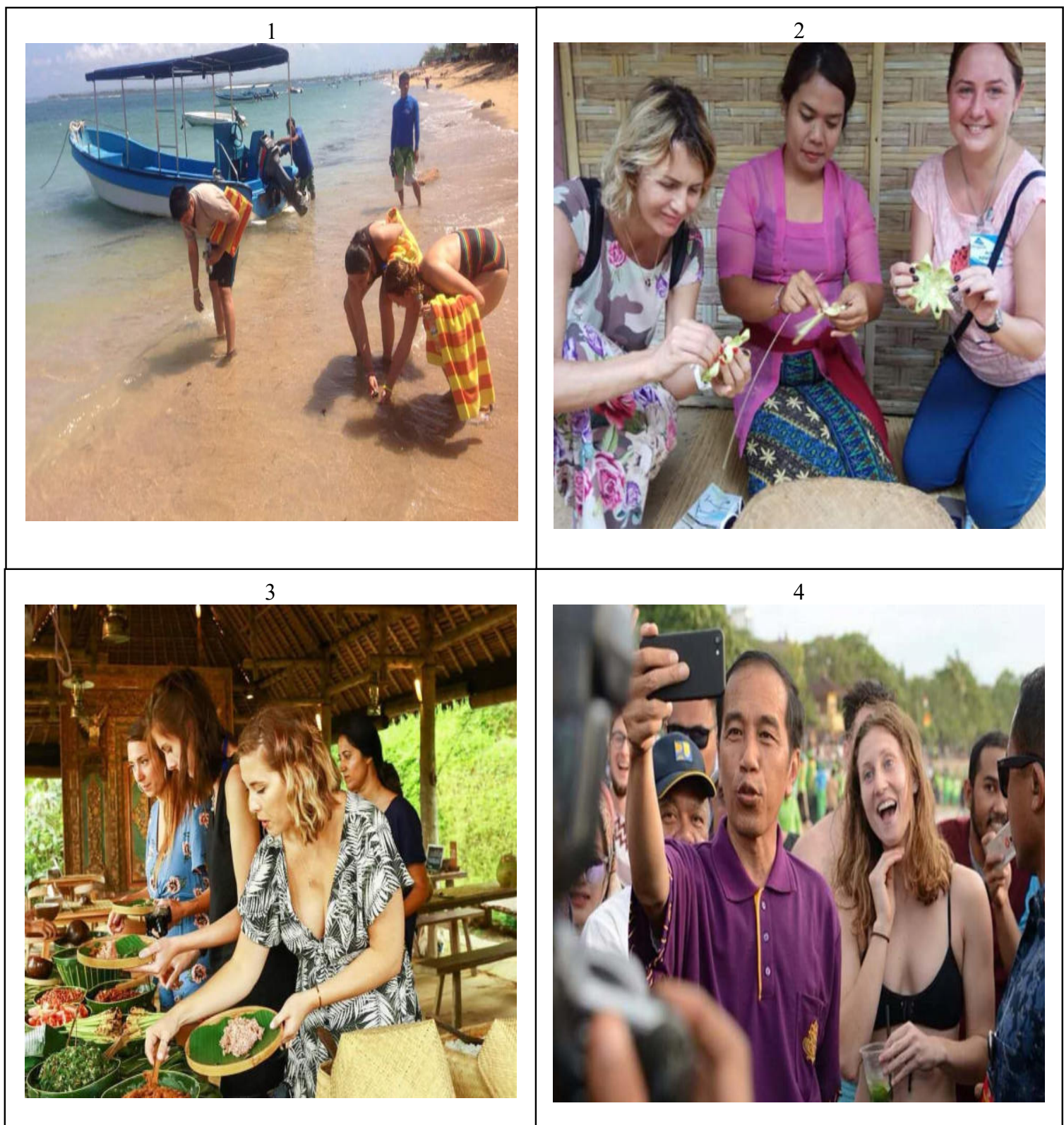

Figure 3. BTB's Pictures. "Universalism" is represented by image showing participation of tourist in an environmental protection project by releasing turtles into the sea representing (picture 1), as well as an image portraying a friendship between local women and tourists (picture 2). Meanwhile, the image of tourists enjoying local food served with traditional way represents "tradition" (picture 3). Lastly, the image of the president of Indonesia, Mr. Jokowi, blending directly with tourists with no strict escort reflects "security" (picture 4)

As presented in the table (3), types of self-transcendence and conservation values are generally promoted prominently by the three selected Instagram categories. In particular, universalism values are prominent in "Indonesia.Travel", Baligolive and BTPB. Tradition values are prominent in BTPB, while stimulation is prominent in "Indonesia.Travel". Finally, hedonism is prominent in "Baligolive". Overall, self-transcendence is the most prominent in all categories of Instagram account, followed by conservation and then openness. Mainly, self-enhancement is not promoted by all types of Instagram. 


\section{Discussion and Conclusion}

Destination image is an issue that is most highlighted by scholars within tourism marketing studies. It was indicated by a trend of the positive growth of literature production dealing with this issue. In the period time from 1973-2000, its quantity of production reached 142 papers (Pike, 2002). Then from 2000 to 2007, its number reached 152 articles circulated, both in the journal tourism or non-tourism (Stepchenkova and Mills, 2010). These authors through his meta-analysis study also added that the growth of the literature spawned several streams of interdisciplinary studies, for instance: sociocultural studies, media studies, studies on destination image and self-concept, and image management policies.

In particular, this study contributes to a theoretical implication relating to human values and social media in the context of tourism marketing through brand construction. It is in line with the notion of brand developed by Batey (2008) viewing value in general as an element associated by the marketer to a brand. Further, this scholar explained through his model of brand evolution, higher-order values of a society is associated with a brand, while it develops as the iconic brand-the highest level of brand evolution.

Additionally, the prominence of values classified into self-transcendence and conservation as presented by all Instagram account categories also can be viewed in perspective linking advertising and culture in a globalization context. It by considering several things. First, indeed the notion of Human value and cultural dimensions conceptualized by the different discipline of studies. The human value derived from psychology study, while cultural aspect derived from cross-cultural research. However, work of Torelli, et al. (2012) shown both of them are universal, interrelated and compared in the process of product purchasing, in which self-achievement and openness relate to individualism, while self-transcendence and conservation relate to collectivism.

Second, some previous studies dealing with the issue of cultural change within globalization indicated advertising media promote both foreign and local culture through circulation of their commercial contents (Cheng, 1997), (Bongjin Cho, Up Kwon, James W. Gentry, 1999) (Wolburg and Kim, 2000) (Zhang and Shavitt, 2003) (Hsu and Barker, 2013). Here, these study findings reinforce those previous studies, as they indicate all agencies of Bali tourism marketer prefer to promote their local value than foreign value. Since, cultural change within Balinese people has developed into a common issue highlighted by scholars, as shown by (Putu Ari Purwanti, 2015), (Ardhana, 2011), (Subawa, 2018).

According to the survey of Hofstede et al. (2010) on cultural differences of IBM employees taken from various countries, Indonesia is classified as a collectivist society. Indeed, there has not been a study that uses this theory in the context of Balinese people to know their cultural character, but collectivism can be attached to the Balinese people as their cultural character. This is by considering two things. First, Bali is a part of Indonesia classified as a collectivist society by Hofstede et al. (2010).

Second, the Balinese culture derived from the Hindu Balinese religion with their Hindu philosophy called "Tri Hita Karana". "Tri" means three, "Hita" means happiness and "Karana" means cause. So, Tri Hita Karana means three causes of human happiness. They are the balances between Man and God (Parahyangan), Man and Man (Pawongan) and Man and Nature ("Palemahan"). Here, collectivism within Balinese culture is indicated by "Pawongan". This is following the meaning of Pawongan itself which reflects the belief in Balinese society that life happiness can be achieved through good relations with humans as shown by mutual respect, mutual respect for others, and mutual help and support (Hutasoit and Wau, 2017).

Also, the dominance of local cultural value represented through self-transcendence and conservation within all Instagram account categories can be understood in the perspective of tourism indigenization. To Hinch and Butler (2007), this process is indicated by which indigenous people are involved within tourism activity as well as indigenous culture is commodified and commercialized to global tourism market to attract a massive flow of tourists. It is as shown by O'Gorman and Thompson (2007) in Mongolia while cultural attractions of "Nadaam" festival is commodified and commercialized for both overseas domestic visitors. Likewise, Pettersson and Viken (2007) demonstrated local tourism entrepreneurs commercialized Sami traditions and Sami narratives. At the same time, Ryan and Trauer (2005) explain media is a factor in indigenous tourism playing a role for tourist's perceived image identification as reference for a marketing strategy and product supplier to deal with the image projection.

Notably, the indigenization in Bali tourism is indicated by several things: First, as determined by the provincial government regulation Number 2/ 2012 that (1) Balinese culture inspired by the teachings of Hinduism and the philosophy of "Tri Hita Karana" is believed as the main potential for the development of Bali tourism (article. 1, point 14); (2) aiming for economic growth (article. 3, point b) and public welfare (article. 4, point b). Second, Balinese culture, mainly their artistic, ritual and religious tradition are served for a tourist attraction ((Picard, 
1990), (Picard, 2008)). Third, media role is shown by their visual contents representing their cultural tradition and value as demonstrated by this study.

\section{Managerial Implications}

By applying visual content analysis, the study successfully identified Schwartz's human values within photographs produced and posted by differences of DMO in context of marketing Bali tourism, in which selftranscendence and conservation were promoted prominently by all DMO categories. The study findings imply these differences of DMO in the context of marketing Bali tourism cooperate in constructing a brand of Bali island by promoting similar values. Seemingly, it is following the model of cooperative branding proposed by Cai (2002) through his study on branding the old west county in which multiple rural communities take apart. Based on the analysis of image attributes, he found the image projected by those communities were perceived consistently by tourists.

On the one hand, the study implies these DMO's successfully cultivate Balinese cultural tourism as a character for the island by associating their tradition and cultural values to the brand of Bali. However, at the same time, constructing the island with specific values precisely narrows the Bali tourism market segment itself. Since theoretically, tourists select a destination for visitation that matches his personal value (Saji et al. 2015) interrelated to his cultural values (Torelli et al. 2012). By this, a tourist with self-enhancement, power values or individualistic value will not visit the island and select other destination, since the island is viewed do not match their both personal and cultural values.

As a solution, DMO promotes differences of values proportionally for branding the island. Possibly, this can be done, as the Island has various types of tourist destinations, including city tours, entertainment, malls, adventure and so on. As Saji et al. (2015) argue those types of destination are theoretically associated with selfenhancement and power values and individualism value. Then, by promoting all Schwartz's values in a balanced manner, the Island will obtain a broad market segment, since the tourists do not perceive the island as a destination associated to specific values.

\section{References}

Akehurst, G. (2009) 'User generated content: The use of blogs for tourism organisations and tourism consumers', Service Business, 3(1), pp. 51-61. doi: 10.1007/s11628-008-0054-2.

Allen, M. W. (2002) 'Human Values and Product Symbolism: Do Consumers Form Product Preference by Comparing the Human Values Symbolized by a Product to the Human Values That They Endorse ?", Journal of Applied Social Psychology, 32(12), pp. 2475-2501.

Allen, M. W. (2008) The Direct and Indirect Influences of Human Values on Consumer Choices. Victoria University of Wellington.

Allen, M. W. and Ng, S. I. K. H. (2003) 'Human values, utilitarian benefits and identification: The case of meat', European journal of social psychooogy, 56(July 2001), pp. 37-56. doi: 10.1002/ejsp.128.

And, R. P. and Viken, A. (2007) 'Sami Perspectives on Indigenous Tourism in Northern Europe: Commerce or Cultural Development?', in Hinch, R. B. and T. (ed.) Tourism and Indigenous Peoples: Issues and Implications. London: Butterworth-Heinemann, pp. 176-187.

Ardhana, I. K. (2011) 'Globalisme dan Multi-Versalisme: Beberapa Catatan tentang Dinamika Sosial Budaya di Bali’, Kajian Bali, 01(2 (Oktober)), pp. 140-158.

Ayeh, J. K., Au, N. and Law, R. (2013) 'Predicting the intention to use consumer-generated media for travel planning’, Tourism Management. Elsevier Ltd, 35, pp. 132-143. doi: 10.1016/j.tourman.2012.06.010.

Bandyopadhyay, R. (2011) 'A Photo Ethnography of Tourism as Neo-Colonialism', Annals of Tourism Research. Elsevier Ltd, 38(2), pp. 714-718. doi: 10.1016/j.annals.2010.12.003.

Bernkopf, D. and Nixon, L. (2018) 'The Impact of Visual Social Media on the Projected Image of a Destination: The Case of Mexico City on Instagram', in Information and Communication Technologies in Tourism 2019. doi: 10.1007/978-3-030-05940-8_12.

Bongjin Cho, Up Kwon, James W. Gentry, S. J. \& F. K. (1999) 'Cultural Values Reflected in Theme and Execution: Commercials Cultural Values Reflected in Theme and Execution: A Comparative Study of U . S . and Korean Television Commercials', Journal of Advertising, 28(4), pp. 59-73. doi: 
$10.1080 / 00913367.1999 .10673596$.

Cai, L. A. (2002) 'Cooperative Branding for Rural Destinations', Annals of Tourism Research, 29(3), pp. 720742.

Cheng, A. and Fleischmann, K. R. (2010) 'Developing a Meta-Inventory of Human Values', in. Pittsburg,PA,USA: ASIST.

Cheng, B. H. (1997) 'Cultural Values Manifest in Advertising: Analysis of Chinese Television Commercials in 1990 and 1995', Journalism\&Mass Communication Quarterly, 74(4), pp. 773-796.

Cohen, A. (2009) 'A value based perspective on commitment in the workplace: An examination of Schwartz's basic human values theory among bank employees in Israel', International Journal of Intercultural Relations, 33(4), pp. 332-345. doi: 10.1016/j.ijintrel.2009.04.001.

Cohen, A. (2010) 'Values and Commitment: A Test of Schwartz's Human Ros, M., Schwartz, S. H., \& Surkiss, S.', Journal of Applied Social Psychology, 40(8), pp. 1921-1947.

Cox, C., Burgess, S. and Sellitto, C. (2009) 'The Role of User-Generated Content in Tourists ' Travel Planning Behavior', Journal of Hospitality Marketing \& Management, 18(8), pp. 743-764. doi: $10.1080 / 19368620903235753$.

Dolores M. Frias, Miguel A. Rodriguez, J. Alberto Castaneda, C. M. S. and D. B. (2011) 'The Formation of a Tourist Destination 's Moderating Effect of Culture', International Journal of Tourism Research. doi: 10.1002/jtr.

Dwivedi, M. (2009) 'Online destination image of India : a consumer based perspective', International Journal of Contemporary Hospitality Management, 21(2), pp. 226-232. doi: 10.1108/09596110910935714.

Gillian Rose (2001) Visual Methodologies. An Introduction to the Interpretation of Visual Materials. First publ. London: Sage.

Grossman-thompson, B. (2016) 'Landscaping Otherness : The Charm of Inequity in Nepali Tourism', Studies in Global Asias, 1(1), pp. 184-211.

Hahm, J. J. and Wang, Y. (2011) 'Film-Induced Tourism as a Vehicle For Destination Marketing: Is it Worth the Efforts?', Journal of Travel \& Tourism Marketing, 28(2), pp. 165-179. doi: 10.1080/10548408.2011.546209.

Heaven, P. C. L. (1993) 'Values and Personality Dimensions : Inventory’, Humanities, I(3), pp. 307-312.

Hofstede, G., Hofstede, G. J. and Minkov, M. (2010) Cultures and Organizations. Software of the Mind. Intercultural Cooperation and Its Importance for Survival. New York: MacGraw-Hill.

Hsu, S. Y. and Barker, G. G. (2013) 'Individualism and collectivism in Chinese and American television advertising', the International Communication Gazette, 75(8), pp. 695-714. doi: 10.1177/1748048513482543.

Huang, Y., Basu, C. and Hsu, M. K. (2010) 'Exploring Motivations of Travel Knowledge Sharing on Social Network Sites : An Empirical Investigation of U . S . College Students', Journal of Hospitality Marketing \& Management, (August 2014), pp. 37-41. doi: 10.1080/19368623.2010.508002.

Hutasoit, H. and Wau, R. (2017) 'Menuju Sustainability Dengan Tri Hita Karana (Sebuah Studi Interpretif Pada Masyarakat Bali)’, Jurnal Manajemen, 13, pp. 151-168.

Inversini, A., Cantoni, L. and Buhalis, D. (2009) 'Destinations 'Information Competition and Web Reputation', Information Technology \& Tourism, 11, pp. 221-234. doi: 10.3727/109830509X12596187863991.

Jenkins, O. (2003) 'Photography and travel brochures: The circle of representation Photography and travel brochures: the circle of representation', An International Journal of Tourism Space, Place and Environment, 5(3), pp. 305-328. doi: 10.1080/14616680309715.

Kavaratzis, M. and Ashworth, G. J. (2005) 'City Branding: An Effective Assertion of Identity or A Transitory Marketing Trick ?', Tijdschrift voor Economische en Sociale Geografi, 96(5), pp. 506-514.

Kevin O'Gorman and Karen Thompson (2007) 'Tourism and culture in Mongolia: the case of the Ulaanbaatar Nadaam', in Hinch, R. B. and T. (ed.) Tourism and Indigenous Peoples: Issues and Implications. London: Butterworth-Heinemann, pp. 161-175.

Kim, S. et al. (2017) 'Effects of tourism information quality in social media on destination image formation: The case of Sina Weibo', Information and Management. Elsevier B.V. doi: 10.1016/j.im.2017.02.009.

Koepfler, J. A. and Fleischmann, K. R. (2011) 'Classifying values in informal communication: Adapting the Meta-Inventory of Human Values for tweets', Proceedings of the ASIST Annual Meeting, 48, pp. 9-12. doi: 


\subsection{2/meet.2011.14504801116.}

Lassar, W., Mittal, B. and Sharma, A. (1995) 'Measuring customer-based brand equity', Journal of Consumer Marketing, 12(4), pp. 11-19.

Lian, T. et al. (2017) 'Representation of Online Image of Tourist Destination: A Content Analysis of Huangshan', Asia Pacific Journal of Tourism Research. Taylor \& Francis, 0(0), pp. 1-20. doi: 10.1080/10941665.2017.1368678.

Lo, I. S. et al. (2011) 'Tourism and online photography', Tourism Management. Elsevier Ltd, 32(4), pp. $725-731$. doi: 10.1016/j.tourman.2010.06.001.

Mackay, K. J. and Couldwell, C. M. (2004) 'Using Visitor-Employed Photography to Investigate Destination Image', Journal of Travel Research, 42(May 2004), pp. 390-396. doi: 10.1177/0047287504263035.

Maria D. Alvarez Meral Korzay (2008) 'Influence of politics and media in the perceptions of Turkey as a tourism destination', Tourism Review, 63(2), pp. 38-46. doi: 10.1108/16605370810883932.

Marzano, G. and Scott, N. (2009) 'Power in Destination Branding', Annals of Tourism Research. Elsevier Ltd, 36(2), pp. 247-267. doi: 10.1016/j.annals.2009.01.004.

Mercille, J. (2005) 'Media Effect on Image: The Case of Tibet', Annals of Tourism Research, 32(4), pp. 10391055. doi: 10.1016/j.annals.2005.02.001.

Minazzi, R. (2015) Social Media Marketing in Tourism and Hospitality. London: Springer International Publishing.

Mok, C. and Defranco, A. L. (2008) 'Chinese Cultural Values: Their Implications for Travel and Tourism Marketing', Journal of Travel \& Tourism Marketing, 8(February 2015), pp. 99-114. doi: 10.1300/J073v08n02.

Muhoho-minni, P. and Lubbe, B. A. (2017) 'The role of the media in constructing a destination image: the Kenya experience', Communicatio, 43, pp. 58-79. doi: 10.1080/02500167.2016.1226915.

Nelson, V. (2005) 'Representation and Images of People, Place and Nature in Grenada's Tourism', Geografiska Annaler, 87 B, pp. 131-143.

Parra-lópez, E. et al. (2011) 'Intentions to use social media in organizing and taking vacation trips', Computer in Human Behavior, 27, pp. 640-654. doi: 10.1016/j.chb.2010.05.022.

Perkins, M. S. and H. C. (2004) 'The Stuff of which Dreams are Made: Representations of the South Sea in German-language Tourist Brochures', Current Issues in Tourism, 7(2), pp. 95-133. doi: $10.1080 / 13683500408667975$.

Picard, M. (1990) " Cultural Tourism " in Bali : Cultural Performances as Tourist Attraction ", Indonesia, (Apr.1990), pp. 37-74.

Picard, M. (2008) 'Balinese identity as tourist attraction', Tourist Studies, 8(2), pp. 155-173. doi: $10.1177 / 1468797608099246$.

Pike, S. (2002) 'Destination image analysis - a review of 142 papers from 1973 to 2000', Tourism Management, 23, pp. 541-549.

Putu Ari Purwanti (2015) 'Gaya Hidup Hedonisme di Kalangan Remaja Putri (Studi Kasus Komunitas Warung Bumi Ayu, Jalan Gunung Agung, Kota Denpasar) Putu Ari Purwanti', Humanis: Journal of Arts and Humanities, 13(3), pp. 1-7. Available at: https://ojs.unud.ac.id/index.php/sastra/article/view/17265.

Sali Saji, M. V. and S. K. (2015) 'Selection of Tourism Destination as a Representation of Human Values', Business Perspective and Research, 3(2), pp. 95-108. doi: 10.1177/2278533715578554.

Schmallegger, D. and Carson, D. (2008) 'Blogs in tourism : Changing approaches to information exchange', Journal of Vacation Marketing, 14(2), pp. 99-110. doi: 10.1177/1356766707087519.

Schwartz, S. H. (1994) 'Are There Universal Aspects in the Structure and Contents of Human Values?', Journal of Social Issues, 50(4), pp. 19-45. doi: 10.1111/j.1540-4560.1994.tb01196.X.

Sheth, J. N., Newman, B. I. and Gross, B. L. (1991) 'Why We Buy What We Buy: A Theory of Consumption Values', Journal of Business Research, 22, pp. 159-170.

Sparks, B. A. and Browning, V. (2011) 'The impact of online reviews on hotel booking intentions and perception of trust', Tourism Management. Elsevier Ltd, 32(6), pp. 1310-1323. doi: 10.1016/j.tourman.2010.12.011.

Stepchenkova, S. and Mills, J. E. (2010) 'Journal of Hospitality Marketing \& Destination Image : A Meta- 
Analysis of 2000 - 2007 Research Destination Image : A Meta-Analysis', Journal of Hospitality Marketing \& Management, 19(6), pp. 575-609. doi: 10.1080/19368623.2010.493071.

Stepchenkova, S. and Zhan, F. (2013) 'Visual destination images of Peru : Comparative content analysis of DMO and user-generated photography q', Tourism Management. Elsevier, 36, pp. 590-601. doi: 10.1016/j.tourman.2012.08.006.

Subawa, I. M. P. (2018) 'Bali dalam Dinamika Masyarakat dan Kebudayaan di Tengah Perkembangan Pariwisata', Pariwisata Budaya, 3, pp. 95-109.

Sweeney, J. C. and Soutar, G. N. (2001) 'Consumer perceived value : The development of a multiple item scale', Journal of Retailing, 77, pp. 203-220.

Teo, L. X., Leng, H. K. and Phua, Y. X. P. (2018) 'Marketing on Instagram. Social Influence and Image Quality on Perception of Quality and Purchase Intention', International Journal of Sports Marketing and Sponsorship. doi: 10.1108/ijsms-04-2018-0028.

Torelli, C. J. et al. (2012) 'Brand Concepts as Representations of Human Values : Do Cultural Congruity and Compatibility Between Values Matter?’, Journal of marketing, 76(July), pp. 92-108.

Trauer, C. R. and B. (2005) 'Conceptualisation and aspiration', in Ryan, C. and Aicken, and M. (eds) Indigenous Tourism - The Commodification and Management of Culture. Oxford: Elsevier, pp. 219-222.

Wang, D., Chan, H. R. and Pan, S. (2014) 'The Impacts of Mass Media on Organic Destination Image : A Case Study of Singapore', Asia Pacific Journal of Tourism Research, pp. 37-41. doi: 10.1080/10941665.2014.948464.

Wolburg, J. M. and Kim, H. (2000) 'Advertising and Culture: Variations on the Theme of Individualism in Korean and American Magazine Advertising', World Communication, 29(2), pp. 63-71.

xiang Li, Bing Pan, Lixuan Zhang, and W. W. S. (2009) 'The Effect of Online Information Insights from a Mixed-Methods Study', Journal of Travel Research, 48(1), pp. 45-57.

Xiang, Z. and Gretzel, U. (2010) 'Role of social media in online travel information search', Tourism Management. Elsevier Ltd, 31(2), pp. 179-188. doi: 10.1016/j.tourman.2009.02.016.

Yoo, K. H. and Gretzel, U. (2010) 'Antecedents and Impacts of Trust in Travel-Related Consumer-Generated Media’, Information Technology \& Tourism, 12, pp. 139-152. doi: 10.3727/109830510X12887971002701.

Young, A. F., Young, R. and Young, A. F. (2008) 'Measuring the Effects of Film and Television on Tourism to Screen Locations: A Theoretical and Empirical Perspective Measuring the Effects of Film and Television on Tourism to Screen Locations: A Theoretical and Empirical Perspective', Journal of Travel and Tourism Marketing, 24(2-3), pp. 195-212. doi: 10.1080/10548400802092742.

Zeithaml, V. A. (1988) 'Consumer Perceptions of Price, Quality, and Value: A Means-End Model and Synthesis of Evidence', Journal of Marketing, 52(3), pp. 2-22.

Zhang, J. and Shavitt, S. (2003) 'Cultural Values in Advertisements to the Chinese X- Generation--Promoting Modernity and Individualism', Journal of Advertising, 32(1), pp. 23-33. doi: 10.1080/00913367.2003.10639047. 